\title{
Hubungan tingkat pengetahuan orang tua tentang kesehatan gigi dengan terjadinya karies pada anak prasekolah di TK Aisyiyah Bustanul Athfal
}

\author{
Siti Fadlilah a, I* \\ a Program Pendidikan Profesi Ners, Universitas Respati Yogyakarta \\ ${ }^{1}$ sitifadlilah@respati.ac.id \\ *korespondensi penulis
}

\begin{tabular}{l}
\hline Informasi artikel \\
\hline Sejarah artikel: \\
Diterima \\
Revisi \\
Dipublikasikan \\
\hline
\end{tabular}

\section{Kata kunci:}

Tingkat pengetahuan Kesehatan gigi

Karies

\begin{abstract}
ABSTRAK
Anak usia prasekolah merupakan masa pertumbuhan bagi seorang anak. Masalah karies merupakan kasus yang dialami oleh anak prasekolah. RISKESDAS, menyatakan Angka kejadian karies di Indonesia mencapai $25,9 \%$. Kondisi ini sangat memprihatinkan mengingat usia anak prasekolah masih membutuhkan peran orang tua dalam merawat kesehatan terutama kesehatan gigi. Dalam hal ini pengetahuan orang tua sangat diperlukan dalam membimbing dan memberikan perhatian yang lebih agar anak tidak mengalami karies. Penelitian ini bertujuan mengetahui hubungan tingkat pengetahuan orang tua tentang kesehatan gigi dengan terjadinya karies pada anak prasekolah di Tk Aisyiyah Bustanul Athfal Wedomartani Ngemplak Sleman Yogyakarta. Penelitian ini merupakan penelitian analitik korelasi dengan pendekatan cross sectional. Subyek penelitian adalah orang tua yang khususnya ibu yang anaknya bersekolah di Tk Aisyiyah Bustanul Athfal. Teknik sampling yang digunakan adalah simpel random sampling sebanyak 64 orang. Alat pengumpulan data menggunakan kuesioner dan lembar observasi. Analisis data penelitian menggunakan analisis Spearman Rank. Tingkat pengetahuan orang tua tentang kesehatan gigi sebagian besar kategori baik (50,0\%). Mayoritas responden mengalami karies (71,9\%). Ha diterima dengan $p$ value $=0,023$, koefisien korelasi $=0,285$. Ada hubungan tingkat pengetahuan orang tua tentang kesehatan gigi dengan terjadinya karies pada anak prasekolah dengan keeratan sedang di TK Aisyiyah Bustanul Athfal Wedomartani Ngemplak Sleman Yogyakarta.
\end{abstract}

Key word:

Knowledge level

Dental health

Dental caries

\begin{abstract}
Relationship between parents' knowledge about dental health and the occurrence of caries in preschool children at Aisyiyah Bustanul Athfal Nursery School. Preschool children is a period of growth for children.Dental caries is often observed among preschool children. The Basic Health Research reports that the prevalence rate of caries in Indonesia reaches $25.9 \%$. This condition is very saddening because preschool-children need their parents to take care of their health, particularly the dental health. In this case, parents' knowledge is very much needed in providing more guidance and care in order that the children do not have dental caries. To was aimed at identifying the correlation between parents' knowledge of dental health with the prevalence of dental
\end{abstract}

DOI: http://dx.doi.org/10.29238 email: jurnalgigijogja@gmail.com 
caries among preschool children at Aisyiyah Bustanul Athfal Nursery School, Wedomartani, Ngemplak, Sleman, Yogyakarta. This research was a correlation analysis with a cross-sectional design. The subjects were parents, particularly mothers, whose children studied at Aisyiyah Bustanul Athfal Nursery School. It was a simple random sampling technique with 64 respondents. The data collection instrument consisted of a questionnaire and an observation sheet. The data were analyzed with the Spearman Rank statistics. This research found that the knowledge of dental health of $50.0 \%$ of the parents was categorized as good, the dental caries prevalence of the childen were $71,9 \%$. The research hypothesis was accepted with a p-value of 0.023 and the correlation coefficient was 0.285 .There was a significant correlation between the parents' knowledge of dental health with the prevalence of dental caries among preschool children at Aisyiyah Bustanul Athfal Nursery School, Wedomartani, Ngemplak, Sleman, Yogyakarta.

This is an openaccess article under the CC-BY-SAlicense.

\section{Pendahuluan}

Kesehatan adalah suatu keadaan sejahtera fisik mental dan sosial yang komplit dan bukan semata-mata terbebas dari penyakit ${ }^{1}$. Kesehatan merupakan suatu faktor yang sangat penting dalam kelangsungan hidup manusia, begitu juga dengan kesehatan gigi. Kesehatan gigi secara tidak langsung menjadi bagian penting dan tidak dapat dipisahkan dari kesehatan tubuh secara umum sehingga merupakan investasi seumur hidup. Penyakit gigi dan mulut yang paling banyak ditemukan di masyarakat luas yaitu karies gigi. Karies tidak hanya terjadi pada orang dewasa tetapi dapat pula terjadi pada anak².

Karies gigi adalah penyakit infeksi yang bersifat progresif serta akumulatif pada jaringan keras gigi yang ditandai dengan kerusakan jaringan, dimulai dari permukaan gigi hingga meluas ke arah pulpa. Gigi berlubang biasanya tidak terasa sakit sampai lubang tersebut bertambah besar dan mengenai persyarafan dari gigi tersebut ${ }^{3}$.Menurut National Institution of Health di Amerika Serikat dilaporkan bahwa karies gigi menjadi penyakit kronis yang paling sering diderita anak umur 5-17 tahun. Prevalensi karies tertinggi terdapat di Asia dan Amerika Latin. Di Asia, karies gigi mencapai angka 30,5\% dan di USA karies gigi merupakan penyakit kronis pada anak yang sering terjadi dan tingkatnya 5 kali lebih tinggi dari asma4.

Faktor utama penyebab karies yaitu host, mikroorganisme, substrat dan ditambah faktor waktu. Selain itu, faktor resiko yang memengaruhi keparahan karies antara lain pengalaman karies, sosial ekonomi, usia, jenis kelamin, pendidikan, geografis, dan perilaku terhadap kesehatan gigi. Pengetahuan juga bisa sebagai faktor-faktor yang menyebabkan karies. Untuk mencegah terjadinya karies pada anak, pengetahuan orang tua menyumbang peranan penting ${ }^{3}$. Umur merupakan salah satu faktor yang dapat menentukan kematangan seseorang baik dalam berfikir, bertindak, maupun belajar. Kematangan dalam berfikir seseorang yang dapat mempengaruhi baik pengetahuan, sikap, maupun praktik seseorang. Karena tahapan kehidupan telah dijalani seseorang dapat memberikan sesuatu pengalaman yang tidak mudah dilupakan?. 
Pengetahuan orang tua sangat diperlukan di dalam membimbing, memberikan pengertian, mengingatkan dan menyediakan fasilitas kepada anak agar dapat memelihara kebersihan. Selain itu, orangtua juga mempunyai peran yang cukup besar di dalam mencegah terjadinya perilaku tidak sehat pada anak ${ }^{5}$. Pada usia anak prasekolah (3-6 tahun) masih sangat tergantung kepada orang tua dan belum bisa mandiri dalam menjaga kebersihan gigi dan mulut. Anak prasekolah dalam melakukan upaya membersihkan gigi dan mulut dengan cara menggosok gigi yang baik dan benar masih membutuhkan peran orang tua. Orang tua harus mengajarkan anak untuk menjaga kebersihan mulut dengan mengosok gigi setelah makan dan sebelum tidur. Karena itu, orang tua sangat perlu melakukan deteksi dini terjadinya karies dan cara skrining untuk mengomtimalkan pengetahuan orang tua dan anak ${ }^{6}$.

Hasil studi pendahuluan di TK Aisyiyah Bustanul Athfal didapatkan data jumlah siswa TK 75 orang. Terbagi Menjadi TK A 25 siswa dan B 50 siswa. Sekolah mempunyai program kesehatan gigi dan mulut dengan mendatangkan petugas puskesmas untuk mengecek gigi dan mulut. Hasil wawancara dengan 10 ibu dari siswa didapatkan data, sebagian besar belum mampu menjawab dengan benar pertanyaan tentang kesehatan gigi dan mulut. Enam dari 10 ibu mengatakan bahwa anaknya mempunyai masalah gigi berlubang. Hasil observasi pada 5 anak-anak di antaranya mengalami masalah gigi yaitu 3 di antaranya gigi berlubang karena karies dan 2 orang anak giginya dicabut dan ditambal karena karies, maka peneliti tertarik untuk melakukan penelitian tentang hubungan tingkat pengetahuan orang tua tentang kesehatan gigi dengan terjadinya karies pada anak prasekolah di TK Aisyiyah Bustanul Athfal Wedomartani Ngemplak Sleman Yogyakarta.

\section{Bahan dan Metode}

Penelitian ini menggunakan desain analitik korelasi dengan pendekatan cross sectional. Penelitian ini dilaksanakan tanggal 26 Januari sampai 2 Februari 2017 di TK Aisyiyah Bustanul Athfal, dengan total populasi adalah 75 orang ibu dan anak. Besar sampel yang diambil 64 orang ibu dan 64 orang anak. Teknik sampling yang digunakan adalah random sampling. Sampel sesuai kriteria ibu pendidikan minimal SMP, ibu usia 21-55 tahun, ibu bersedia menjadi responden, ibu mampu berkomunikasi dan bisa membaca, ibu dan anak masih tinggal dalam 1 rumah, dan anak yang mempunyai ibu. Instrumen yang digunakan untuk mengukur pengetahuan adalah kuesioner. Kuesioner pengetahuan tentang definisi kesehatan gigi, masalah-masalah gigi, penyebab masalah gigi, definisi karies gigi dan pencegahan karies gigi. Sedangkan data karies gigi didapatkan dengan pemeriksaan dan diagnosis oleh dokter gigi. Kuesioner dilakukan uji validitas dan reliabilitas dengan bantuan komputerisasi menggunakan rumus Pearson Product Moment untuk uji validitas dan rumus Alpha Croanbach untuk uji reliabilitas. Uji statistik yang digunakan pada penelitian ini adalah uji statistik Spearman Rank? 


\section{Hasil dan Pembahasan}

Tabel 1. Distribusi frekuensi karakteristik orang tua dan anak di TK Aisyiyah Bustanul Athfal Wedomartani Ngemplak Sleman Yogyakarta

\begin{tabular}{ccc}
\hline Karakteristik & Frekuensi & Presentase \\
\hline Umur ibu & & \\
$9-25$ tahun & 3 & 4,7 \\
$25-40$ tahun & 54 & 84,4 \\
$>40$ tahun & 7 & 10,9 \\
Pendidikan ibu & & \\
SMP & 12 & 18,8 \\
SMA & 30 & 46,9 \\
Perguruan Tinggi & 22 & 34,4 \\
Pekerjaan ibu & & \\
Ibu Rumah Tangga & 39 & 60,9 \\
Buruh & 4 & 6,2 \\
Guru & 2 & 3,1 \\
Swasta & 19 & 29,7 \\
Umur anak & & \\
4 tahun & 2 & 3,1 \\
5 tahun & 31 & 48,4 \\
6 tahun & 31 & 48,4 \\
Jenis kelamin anak & & 54,7 \\
Perempuan & 35 & 45,3 \\
Laki-laki & 29 & 100,0 \\
\hline Total & 64 &
\end{tabular}

Tabel 2. Tingkat pengetahuan orang tua tentang kesehatan gigi di TK Aisyiyah Bustanul Athfal Wedomartani, Ngemplak, Sleman Yogyakarta

\begin{tabular}{ccc}
\hline Pengetahuan & Frekuensi & Presentase \\
\hline Baik & 32 & 52,0 \\
Cukup & 30 & 46,9 \\
Kurang & 2 & 3,1 \\
\hline Total & 64 & 100,0 \\
\hline
\end{tabular}

Tabel 2 diketahui tingkat pengetahuan orang tua tentang kesehatan gigi sebagian besar dalam kategori baik yaitu sebanyak 32 orang (50\%).

Tabel 3. Tabulasi silang tingkat pengetahuan orang tua dengan pendidikan orang tua di TK Aisyiyah Bustanul Athfal Wedomartani, Ngemplak, Sleman Yogyakarta

\begin{tabular}{ccccccc}
\hline \multirow{2}{*}{ Pendidikan } & \multicolumn{7}{c}{ Pengetahuan } \\
\cline { 2 - 7 } & B & Baik & Cukup & Kurang \\
\cline { 2 - 7 } & 5 & 7,8 & 7 & 10,9 & 0 & f \\
\hline Baik & 13 & 20,3 & 15 & 23,4 & 2 & 0,0 \\
Cukup & 14 & 21,9 & 8 & 12,5 & 0 & 3,1 \\
Kurang & 32 & 50,0 & 30 & 46,9 & 2 & 0,0 \\
\hline Total & &
\end{tabular}


Tabel 4. Tabulasi silang tingkat pengetahuan orang tua dengan pekerjaan orang tua di TK Aisyiyah Bustanul Athfal Wedomartani, Ngemplak, Sleman Yogyakarta

\begin{tabular}{ccccccc}
\hline \multirow{2}{*}{ Pekerjaan } & \multicolumn{7}{c}{ Pengetahuan } \\
\cline { 2 - 7 } & \multicolumn{2}{c}{ Baik } & Cukup & \multicolumn{2}{c}{ Kurang } \\
\cline { 2 - 7 } & $\mathrm{f}$ & $\%$ & $\mathrm{~F}$ & $\%$ & $\mathrm{f}$ & $\%$ \\
\hline IRT & 20 & 31,2 & 18 & 28,1 & 1 & 1,6 \\
Buruh & 2 & 3,1 & 1 & 1,6 & 1 & 1,6 \\
Guru & 2 & 3,1 & 0 & 0,0 & 0 & 0,0 \\
Swasta & 8 & 12,5 & 11 & 17,2 & 0 & 0,0 \\
\hline Total & 32 & 50,0 & 30 & 46,9 & 2 & 3,1 \\
\hline
\end{tabular}

Tabel 5. Tabulasi silang tingkat pengetahuan orang tua dengan umur orang tua di TK Aisyiyah Bustanul Athfal Wedomartani, Ngemplak, Sleman Yogyakarta

\begin{tabular}{cccccccc}
\hline & \multicolumn{9}{c}{ Pengetahuan } \\
\cline { 2 - 7 } Umur & \multicolumn{2}{c}{ Baik } & Cukup & Kurang \\
\cline { 2 - 7 } & $\mathrm{f}$ & $\%$ & $\mathrm{f}$ & $\%$ & $\mathrm{f}$ & $\%$ \\
\hline $19-25$ & 2 & 3,1 & 1 & 1,6 & 0 & 0,0 \\
$25-40$ & 26 & 40,6 & 26 & 40,6 & 2 & 3,1 \\
$>40$ & 4 & 6,2 & 3 & 4,7 & 0 & 0,0 \\
\hline Total & 32 & 50,0 & 30 & 46,9 & 2 & 3,1 \\
\hline
\end{tabular}

Tabel 6. Terjadinya karies pada anak prasekolah di TK Aisyiyah Bustanul Athfal Wedomartani, Ngemplak, Sleman Yogyakarta

\begin{tabular}{ccc}
\hline Terjadinya karies & Frekuensi & Presentase \\
\hline Karies & 46 & 71,9 \\
Tidak karies & 18 & 28,1 \\
\hline Total & 64 & 100,0 \\
\hline
\end{tabular}

Tabel 6 diketahui bahwa sebagian besar anak mengalami karies gigi yaitu sebanyak 46 orang $(71,9 \%)$.

Tabel 7. Tabulasi silang tingkat pengetahuan orang tua tentang kesehatan gigi dengan tejadinya karies pada anak prasekolah di TK Aisyiyah Bustanul Athfal Wedomartani, Ngemplak, Sleman Yogyakarta

\begin{tabular}{|c|c|c|c|c|c|c|c|c|}
\hline \multirow{3}{*}{ Pengetahuan } & \multicolumn{4}{|c|}{ Karies pada Anak } & \multirow{2}{*}{\multicolumn{2}{|c|}{ Total }} & \multirow{3}{*}{$\rho$} & \multirow{3}{*}{$P$} \\
\hline & \multicolumn{2}{|c|}{ Karies } & \multicolumn{2}{|c|}{$\begin{array}{l}\text { Tidak } \\
\text { Karies } \\
\end{array}$} & & & & \\
\hline & $f$ & $\%$ & $f$ & $\%$ & $\mathrm{~F}$ & $\%$ & & \\
\hline Baik & 19 & 29,7 & 13 & 20,3 & 32 & 50,0 & & \\
\hline Cukup & 25 & 39,1 & 5 & 7,8 & 30 & 46,9 & 0,285 & 0,023 \\
\hline Kurang & 2 & 3,1 & 0 & 0,0 & 2 & 3,1 & & \\
\hline Total & 46 & 71,9 & 18 & 28,1 & 64 & 100,0 & & \\
\hline
\end{tabular}

Tabel 7, diketahui 32 ibu mempunyai tingkat pengetahuan baik, mayoritas mempunyai anak dengan karies yaitu sebanyak 19 orang (29,7\%). Dari 30 ibu yang mempunyai pengetahuan cukup mayoritas mempunyai anak dengan karies yaitu 25 orang (39,1\%). Sedangkan dua ibu yang mempunyai pengetahuan kurang seluruh anaknya mengalami karies. 
Tabel 2 diketahui tingkat pengetahuan orang tua tentang kesehatan gigi pada anak prasekolah di TK Aisyiyah Bustanul Athfal Wedomertani, Ngemplak, Sleman Yogyakarta 32 responden kategori baik (50,0\%). 30 kategori cukup (46,9\%), dan 2 orang kategori kurang $(3,1 \%)$. Dalam hal ini tingkat pengetahuan ibu tentang kesehatan gigi mayoritas berada dalam kategori baik (50,0\%).

Pengetahuan merupakan suatu usaha manusia untuk mengetahui, memahami dan mampu untuk mengungkapkan semua yang dipikirkan baik itu berupa pendapat, jawaban lisan maupun tertulis. Pengetahuan juga dapat mempengaruhi tindakan seseorang baik itu tindakan yang baik dan tindakan yang buruk ${ }^{5}$. Pengetahuan dalam penelitian ini adalah hasil tahu orang tua tentang kesehatan gigi. Pengetahuan adalah hasil tahu orang tua bagaimana cara untuk melakukan perawatan gigi, kapan waktu untuk melakukan pemeriksaan gigi. Dalam hal ini pengetahuan orang tua dikategorikan menjadi tiga yaitu pengetahuan baik, cukup, dan kurang.

Pengetahuan kategori baik pada penelitian ini dapat diartikan bahwa orang tua mempunyai pemahaman yang benar tentang kesehatan gigi anak. Orang tua anak mampu mengingat, menjelaskan secara benar materi tentang kesehatan gigi anak dengan benar yang dapat dilihat dari hasil jawaban kuesioner. Kuisioner peneliti terdiri dari aspek definisi kesehatan gigi dan karies, penyebab masalah gigi, masalah-masalah gigi, tanda karies gigi, pencegahan karies.

Tabel 3 diketahu dari 32 responden dengan tingkat pengetahuan baik mayoritas 14 responden perguruan tinggi dan 30 rasponden dengan tingkat pengetahuan cukup 15 berpendidikan SMA Dari hasil tabulasi silang antara tingkat pengetahuan orang tua dengan pendidikan orang tua orang tua pada tabel 3 didapatkan hasil semakin tinggi pendidikan semakin tinggi pengetahuan. Dimana semakin tinggi pendidikan maka pengetahuan semakin baik ${ }^{5}$.

Tabel 4 diketahui dari 39 responden dengan pekerjaan sebagai Ibu rumah tangga mayoritas 20 responden kategori pengetahuan baik. Hasil tabulasi silang tingkat pengetahuan dengan pekerjaan orang tua dilihat dari tabel 4 karena 20 responden sebagai ibu rumah tangga 11 di antaranya berpendidikan perguruan tinggi. Pekerjaan merupakan kegiatan yang menyita waktu sehingga pekerjaan mempunyai pengaruh terhadap keluarga ${ }^{5}$.

Tabel 5 diketahui dari hasil tabulasi silang tingkat pengetahuan orang tua dengan umur orang tua didapatkan hasil pada dewasa tengah 25-40 tahun didapatkan pengetahuan orang tua berada dalam kategori baik dan cukup. Menyatakan pengalaman dapat diperoleh dari diri sendiri maupun dari orang lain sehingga semakin bertambahnya umur dan pengalaman tentunya dapat memperluas pengetahuan seseorang 5 .

Tabel 6 kejadian karies pada Anak Prasekolah di TK Aisyiyah Bustanul Athfal Wedomartani, Ngemplak, Sleman Yogyakarta sebanyak 46 orang $(71,9 \%)$ dalam kategori karies sedangkan 18 orang (28,1\%) dalam kategori tidak karies. Dalam hal ini kejadian karies pada anak prasekolah mayoritas mengalami karies. Hasil ini menunjukkan bahwa anak belum mampu merawat giginya sendiri dengan baik. Hasil penelitian mendukung penelitian dengan judul, "Gambaran Status Karies Gigi Anak Usia 11-12 Tahun Pada Keluarga Pemegang Jamkesmas Di Kelurahan Tumatangtang I Kecamatan Tomohon 
Selatan". Hasil penelitian memperlihatkan dari pemeriksaan DMF-T pada 54 anak didapatkan total indeks Decay (D) berjumlah 159, Missing (M) berjumlah 45, dan Filling (F) tidak ada, dengan indeks DMF-T rata-rata 3,8 (kategori status karies sedang berdasarkan kriteria $\mathrm{WHO})^{7}$.

Hasil analisis data diketahui keeratan hubungan tingkat pengetahuan orang tua tentang kesehatan gigi dengan terjadinya karies pada anak prasekolah di TK Aisyiyah Bustanul Athfal Wedomartani, Ngemplak, Sleman Yogyakarta kategori sedang (koefisien korelasi=0,285). Hal ini dapat diartikan bahwa pengetahuan tentang kesehatan gigi mempunyai kontribusi signifikan terhadap terbentuknya karies pada anak ${ }^{3}$.

Penelitian tentang, "Faktor-Faktor yang Mempengaruhi Kejadian Karies Gigi Pada Siswa Kelas 1 di SD Negeri 1 Pekkae Kecamatan Tanete Rilau Kabupaten Barru". Faktorfaktor terdiri dari pola makan, personal hygiene, dan gaya hidup. Hasil penelitian menunjukkan ada pengaruh hubungan antara pola makan personal hygiene dan gaya hidup terhadap karies gigi ${ }^{11}$. Personal hygiene yang baik salah satunya dipengaruhi oleh tingkat pengetahuan tentang kesehatan gigi yang baik.

Hasil penelitian ini mendukung hasil penelitian sebelumnya dengan hasil adanya hubungan yang signifikan antara pengetahuan orang tua dengan kejadian karies gigi pada anak di SDN V Jaten Karanganyar. Kesamaan hasil penelitian ini dengan penelitian sebelumnya menunjukkan bahwa pengetahuan yang dimiliki oleh orang tua, berpengaruh terhadap terbentuknya karies pada anak7.

\section{Kesimpulan}

Hasil penelitian menunjukkan bahwa tingkat pengetahuan ibu tentang kesehatan gigi berhubungan dengan kejadian karies gigi pada anak pra sekolah. Berdasarkan hasil penelitian diharapkan ibu yang mempunyai anak pra sekolah dapat meningkatkan pengetahuan tentang kesehatan gigi sehingga kebersihan gigi anak dapat terjaga dan mencegah kajadian karies.

\section{Ucapan Terima Kasih}

Peneliti mengucapkan terima kasih kepada Ketua Program Pendidikan Profesi Ners dan LPPP Universitas Respati Yogyakarta yang telah mendukung terlaksananya penelitian ini.

\section{Daftar Pustaka}

I. Wong, L, dkk. 2008. Buku Ajar Keperawtan Pediatrik ed 6. Jakarta. EGC.

2. Riset Kesehatan Dasar. 2013. Kesehatan Gigi dan Mulut hal.IIdanI47. Jakarta. I desember 2013.

3. Tarigan. 2012. Karies Gigi, Ed 2. Jakarta: EGC

4. Nursalam. 20I I. Penerapan Metodologi Penelitian Ilmu Keperawatan. Jakarta: Salemba Medika.

5. Notoatmodjo, S. 2003. Metodologi Penelitian Kesehatan. Jakarta: Rineka Cipta

6. Soetjoningsih. 2012. Tumbuh Kembang Anak. Jakarta: EGC.

7. Hansen Ch. Wala. 2013. Gambaran Status Karies Gigi Anak Usia II-I2 Tahun Pada Keluarga Pemegang Jamkesmas Di Kelurahan Tumatangtang I Kecamatan Tomohon SELATAN.Skripsi. Universitas Sam Ratulangi Manado.

8. Riset Kesehatan Dasar. 2007. Kesehatan Gigi dan Mulut. Jakarta. 2007.

9. Yulianti, R. P., \& Muhlisin, A. 20I I. Hubungan Antara Pengetahuan Orang Tua Tentang Kesehatan Gigi dan Mulut Dengan Kejadian Karies Gigi Pada Anak Di SDN V Jaten Karanganyar. Skripsi.Universitas Muhammadiyah Surakarta 
I0. Kusumawardani, E. 20I I. Burukknya Kesehatan Gigi dan Mulut. Yogyakarta: Siklus

II. Sariningsih. 20I4. Gigi Busuk dan Poket Periodental Sebagai Fokus Infeksi. Jakarta:Elek Media Komputindo.

I2. Nirham. 20I4. FAKTOR - Faktor Yang Mempengaruhi Kejadian Karies Gigi Pada Siswa Kelas I Di Sd Negeri I Pekkae Kecamatan Tanete Rilau Kabupaten Barru. Skripsi.Stikes Nani Hasanuddin Makassar. 